Открытые информационные и компьютерные интегрированные технологии № 81, 2018

doi:10.32620/oikit.2018.81.10

УДК 629.7.036.3

Дуаиссиа Омар Хадж Аисса

\title{
Численное исследование теплоотдачи в камере подшипника ГТД
}

\author{
Национальный аэрокосмический университет им. Н.Е. Жуковского \\ «Харьковский авиационный институт»
}

\begin{abstract}
Для определения потребной прокачки масла через опору ротора ГТД необходим точный расчёт теплового потока от двигателя в камеру подшипника ГТД. Сложность математического описания теплогидравлических процессов связана с наличием многофазной смеси в камере подшипника, состоящей из масла, идущего на смазку и охлаждение элементов опоры, и воздуха, используемого для наддува уплотнений. Работа посвящена вопросам численного исследования влияния режимных параметров на коэффициент теплоотдачи в камере подшипника ГТД. Для этого применена методология, базирующаяся на законах сохранения и методах CFD моделирования. Рассмотрено изменение коэффрициента теплоотдачи в характерных сечениях камеры. Показано влияние распределения масляной пленки по окружности камеры на коэфффициент теплоотдачи.
\end{abstract}

Ключевые слова: газотурбинный двигатель, режимные параметры, коэффициент теплоотдачи, опора ротора, камера подшипника, CFD-моделирование.

\section{Введение}

Основным элементом системы смазки авиационного двигателя является опора ротора. Деталями и узлами двигателя вокруг каждой опоры создается замкнутое пространство - масляная полость (камера подшипника), в котором осуществляется подача масла на подшипник и его откачка для исключения утечки масла из масляной полости опоры через уплотнения в предмасляной полости создается большее давление за счет наддува воздухом, чаще всего отбираемым от компрессора ГТД. В результате этого при работе двигателя в масляной полости опоры присутствует не однофразная среда - масло, а его смесь с воздухом, что в значительной степени влияет на протекание теплогидравлических процессов в камере подшипника.

Конструкции опор ГТД весьма разнообразны [1], учитывают индивидуальные особенности конкретного двигателя и практически не повторяются в различных разработках. В своей основе они могут иметь роликовый или шариковый радиально-упорный подшипник. Однако в конструкции опор можно выделить группы элементов, имеющих единое функциональное назначение, такие, как статорная и роторная части, подшипник.

Для создания экономичных двигателей новых поколений затраты мощности на прокачку масла к узлам трения, а также количество воздуха, отбираемого из воздушного тракта двигателя для наддува и тепловой защиты камер подшипников, стремятся свести к минимуму, необходимому для его надежной работы. Определение потребной прокачки масла напрямую связано с тепловым потоком от двигателя в камеру подшипника, который состоит из нескольких составляющих [2]. К ним относятся тепловые потоки: из тракта; через стенки опоры; через вал; от трения в уплотнениях; от трения в подшипниках, зубчатых передачах, шлицевых соединениях и т.п.; от воздуха, поступающего через уплотнения. Для расчета большинства из указанных составляющих теплового потока необходимо точно 
знать величину коэффрициента теплоотдачи в камере подшипника, который, в свою очередь, значительно зависит от картины течения воздушно-масляной смеси в камере.

Целью данной работы является проведение численного исследования влияния режимных параметров на коэффициент теплоотдачи в характерных сечениях камеры подшипника с учетом распределения масляной пленки по окружности камеры. Кроме того, в работе проведена проверка применимости корреляционной зависимости [3] для расчета среднего коэфффициента теплоотдачи в камере подшипника.

\section{1. Объект исследования и физическая модель процессов}

В качестве объекта исследований была выбрана камера подшипника II (рис. 1), представленная в работах [3, 4]. Данный выбор обуславливался необходимостью верификации созданной CFD модели теплогидравлических процессов в камере подшипника [5].

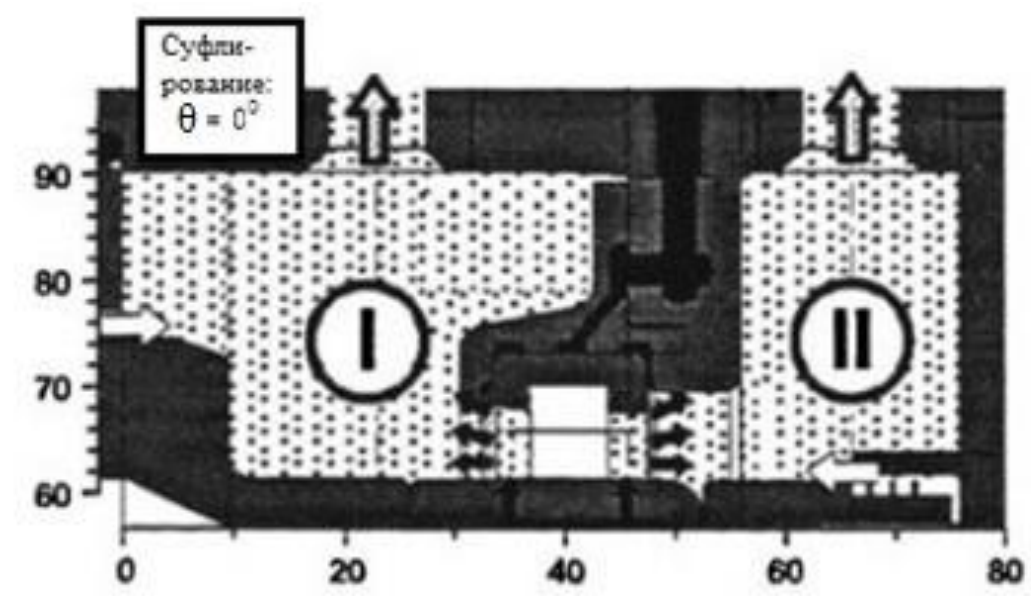

Рис. 1.Экспериментальная камера подшипника [3, 4]

Камера II образована вращающимся валом и неподвижным корпусом. Радиус вала равен 62 мм, высота камеры h составляет 28 мм, а ширина b - 20 мм. Разогретое масло подается под внутреннее кольцо роликового подшипника. Для предотвращения утечки масла из камеры использовано лабиринтное уплотнение, через которое проникает воздух, нагретый до той же температуры, что и смазочное масло. Воздушно-масляная смесь удаляется из камеры через трубопровод суфлирования, расположенный в верхней части камеры, и откачивающий трубопровод - в нижней части (на рис.2) не показан. Трубопроводы имеют внутренний диаметр 10 мм. Для обеспечения визуального наблюдения за поведением потока правая боковая стенка камеры II выполнена из высокотемпературного термопластичного прозрачного материала (MAKROLON).

Коэффрициент теплоотдачи в камере подшипника зависит от структуры потока, частоты вращения вала, расхода впрыскиваемого масла и воздуха, прошедшего через уплотнения, геометрических размеров полости и т.д. [2, 5]. На рис. 2 показана возможная структура потока в масляной полости опоры [2, 6]. 


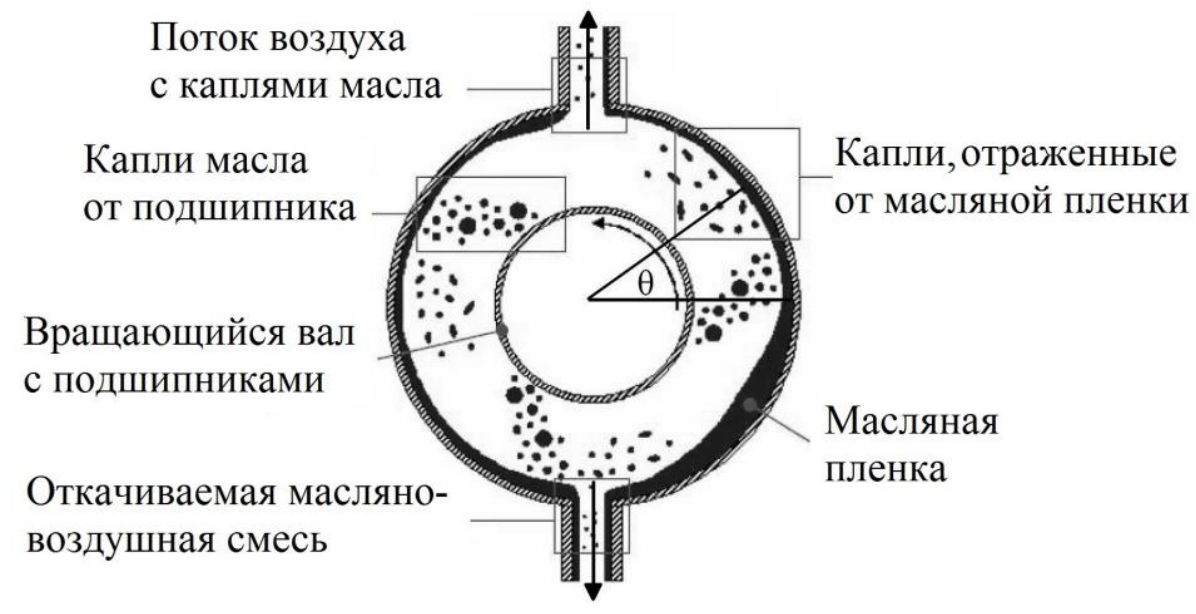

Рис.2. Структура потока в масляной полости опоры

Масло, попадая через фрорсунку на поверхность подшипника, растекается по его поверхности, образуя масляную пленку. Под действием центробежных сил и сил со стороны воздушного потока капли масла отделяются от масляной пленки подшипника и уносятся к внутренней поверхности камеры. В процессе этого движения капли обмениваются импульсом и энергией с потоком воздуха. Попадая на стенку камеры, капли масла формируют пленку, движущуюся под действием аэродинамических сил на межфазной поверхности, сил тяжести и вязкости. На образованную пленку оказывают влияние как капли, попадающие на нее от подшипника, так и воздушный поток, который может срывать и уносить капли с поверхности пленки. В результате такого сложного взаимодействия масляная пленка имеет переменную толщину по окружности камеры подшипника, что влияет на процесс теплообмена между стенками камеры и масляно-воздушной смесью, что показано в [5].

\section{2. Потокораспределение и теплообмен в камере подшипника}

Сечение, проходящее через суфлирующую и откачивающую магистрали, соответствующее угловой координате 0 и 180', делит камеру подшипника на две симметричные части (см. рис. 3), в которых теплогидравлические процессы протекают несимметрично. Это связано с изменением направления действующих сил: сил тяжести и сдвига (касательного напряжения) на межфазной поверхности пленка/воздух+капли, а также других факторов. Рассмотрим протекание теплогидравлических процессов в камере подшипника на примере режима 1 (табл. 1).

Таблица 1

Режимы работы камеры подшипника

\begin{tabular}{|c|c|c|c|}
\hline Режим & $\begin{array}{c}\text { Частота вращения } \\
\text { вала, об/мин }\end{array}$ & $\begin{array}{c}\text { Расход масла от } \\
\text { подшипника, л/ч }\end{array}$ & $\begin{array}{c}\text { Расход воздуха через } \\
\text { уплотнение, г/с }\end{array}$ \\
\hline 1 & 9000 & 50 & 15 \\
\hline 2 & 9000 & 100 & 15 \\
\hline 3 & 16000 & 50 & 15 \\
\hline
\end{tabular}




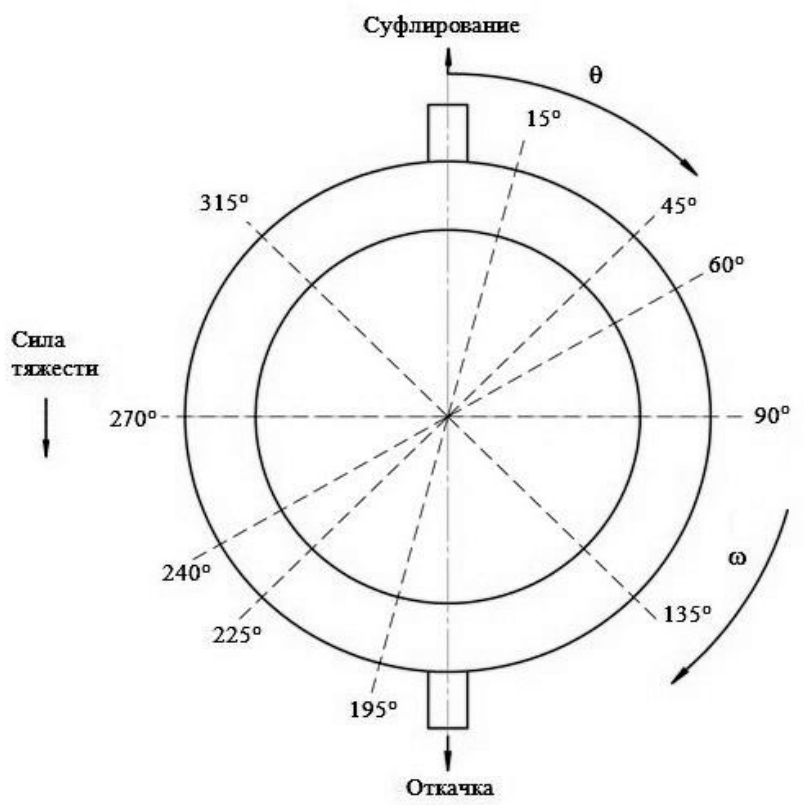

Рис. 3. Схема угловых сечений камеры подшипника

Под действием потока воздуха и центробежных сил капли масла перемещаются к стенке камеры, что приводит к формированию масляной пленки на ее поверхности. Как показывают результаты моделирования (рис. 4), наблюдается неравномерное распределение толщины масляной пленки по окружности камеры. Силы тяжести и касательного напряжения на межфазной границе (пленка / воздух+капли) оказывают влияние на движение пленки.

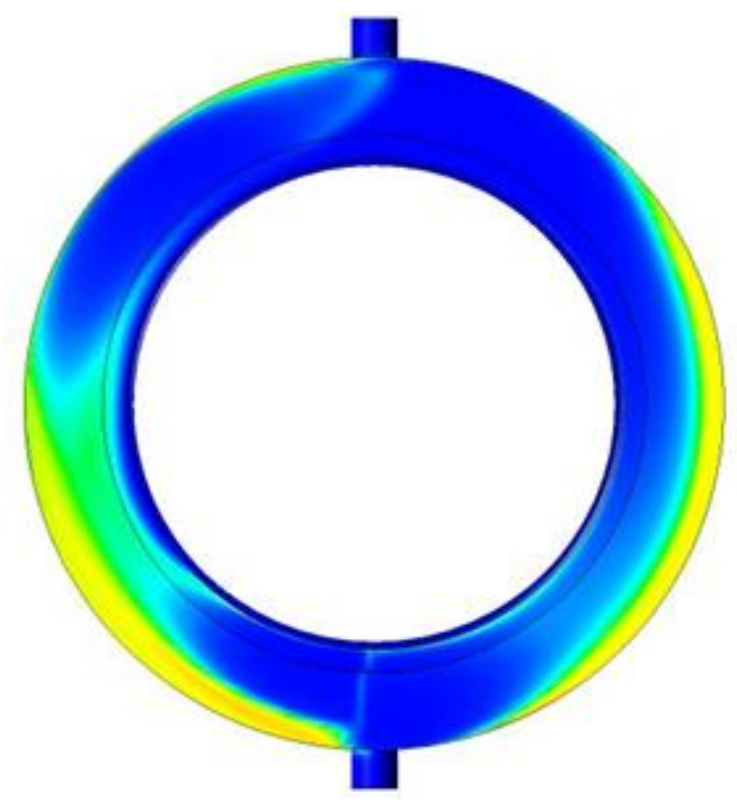

Рис. 4. Распределение пленки масла по окружности камеры подшипника

Под действием сил тяжести пленка стремится в нижнюю часть камеры, где расположен канал для откачки масловоздушной смеси. В свою очередь, вращающийся вал вовлекает поток воздуха, прошедший через уплотнения, в круговое 
движение вдоль стенок камеры. В области, где направление движения воздушного потока совпадает с направлением течения пленки (правая часть камеры рис. 4, 5), ее скорость увеличивается, а толщина соответственно уменьшается. Однако в левой части камеры направления движения пленки масла и воздуха не совпадают, что приводит к торможению потока масляной пленки на поверхности камеры и, как следствие, к увеличению ее толщины. В левой части камеры наблюдается фрормирование пленки в зоне расположения канала суфлирования, что способствует попаданию масла в суфлирующий канал. Этот факт подтверждается экспериментальными исследованиями [7].

В результате неоднородного распределения пленки масла на стенках камеры и сложного движения потока воздуха, содержащего капли масла, в объеме камеры подшипника будет наблюдаться изменение термического сопротивления пограничного слоя и, следовательно, коэффициента теплоотдачи, что подтверждается результатами численного моделирования. Для режима 1 (табл. 1) распределение осредненного вдоль цилиндрической части камеры коэффрициента теплоотдачи по сечениям камеры, обозначенным на рис. 3, показано на рис. 5.

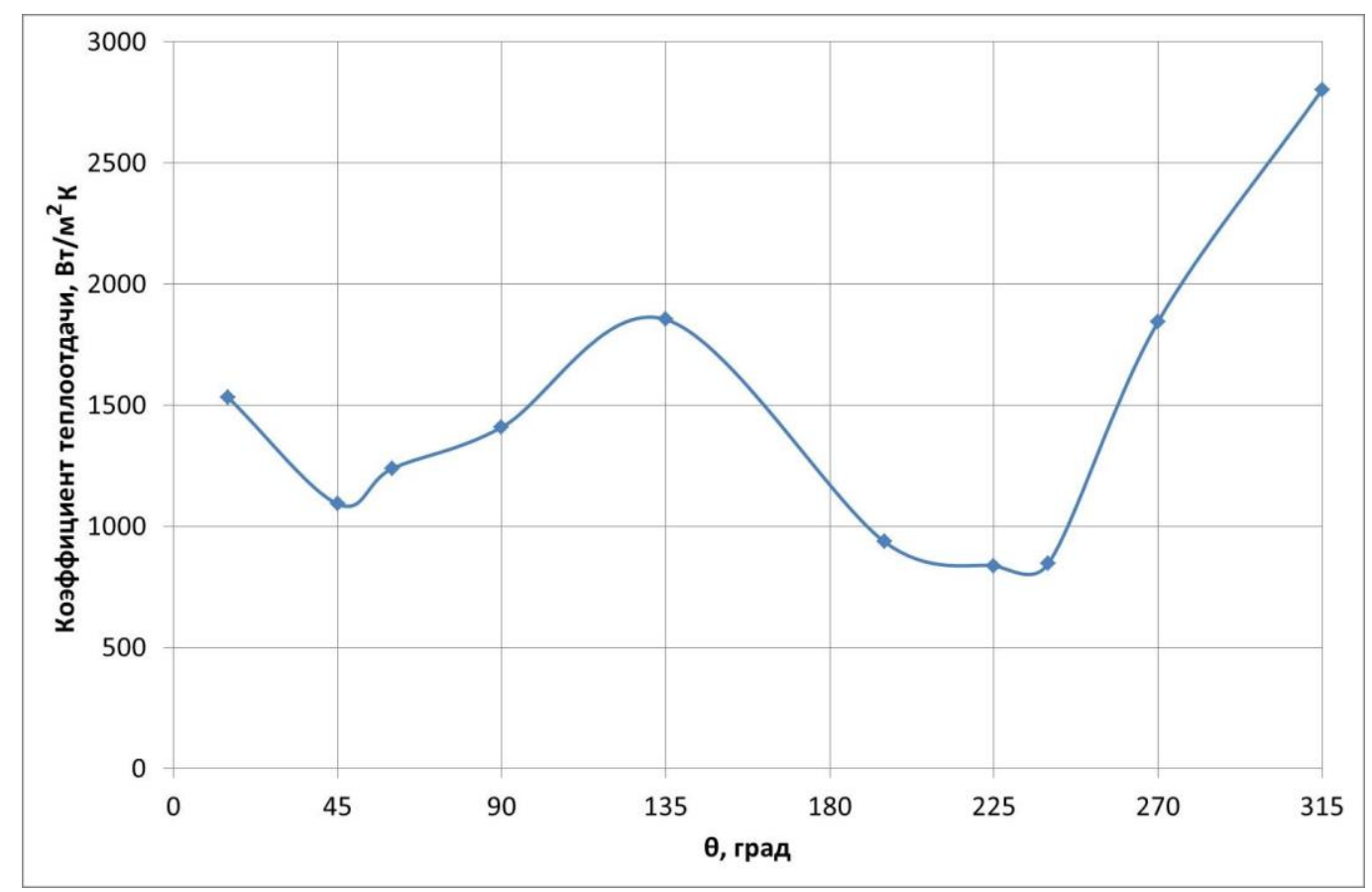

Рис. 5. Распределение среднего коэффрициента теплоотдачи по сечениям камеры (режим 1)

Из рис. 5 видно, что минимальный коэфффициент теплоотдачи наблюдается в нижней части камеры, что соответствует угловым координатам $195 \ldots 240^{\circ}$, где происходит обильное формирование масляной пленки на стенках камеры. При этом импульса капель, взаимодействующих с поверхностью пленки, оказывается недостаточно, чтобы разрушить сформировавшуюся пленку и оказать существенное влияние на течение в пристеночной области. В результате этого термическое сопротивление пограничного слоя увеличивается и, как следствие, уменьшается коэффицциент теплоотдачи. В верхней части камеры, особенно в области $270 \ldots 315^{\circ}$, где не происходит фоормирование слоя пленки на стенках камеры или фрормируется тонкий ее слой, поток капель при взаимодействии с такой поверхно- 
стью уменьшает термическое сопротивление пограничного слоя, что приводит к росту коэффициента теплоотдачи.

\section{3. Влияние частоты вращения ротора и расхода масла на коэффициент теплоотдачи}

Используя разработанную методологию, реализованную с использованием CFD моделирования, рассмотрим изменение коэффиццента теплоотдачи по окружности камеры подшипника для трех режимов, представленных в табл. 1. Режимы характеризуются вариацией расходов масла для смазки подшипника 50 и 100 л/ч - режимы 1 и 2, а также частот вращения ротора 9000 и 16000 об/мин режимы 1 и 3. При этом сохраняется постоянство расхода воздуха на наддув уплотнений, равное 15 г/с.

На рис. 6 для режимов 1 и 2 показано распределение по окружности камеры подшипника (рис. 3), осредненного вдоль цилиндрической части камеры коэффициента теплоотдачи. Как видно из рис. 6, увеличение расхода масла для смазки подшипника с 50 до 100 л/ч приводит к образованию большего количества капель, движущихся в воздушном потоке и интенсивно взаимодействующих с поверхностью стенок камеры и пленки масла, что приводит к росту значений коэфрфициента теплоотдачи в 1,3 раза. При этом характер изменения коэфффициента теплоотдачи практически сохраняется.

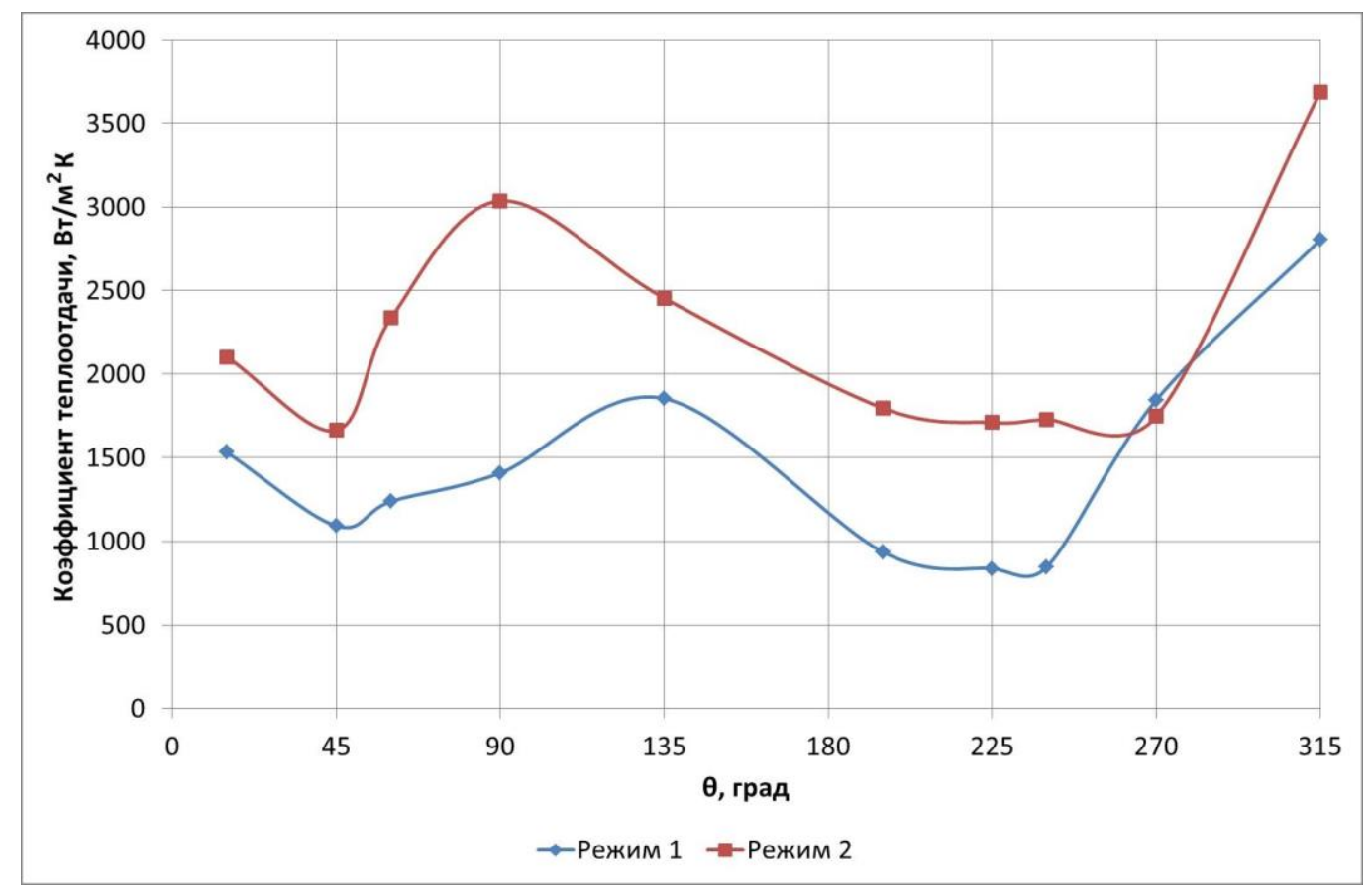

Рис. 6. Распределение среднего коэффициента теплоотдачи по сечениям камеры (режимы 1 и 2)

Влияние частоты вращения ротора на величину и характер распределения по окружности камеры подшипника (рис. 3), осредненного вдоль цилиндрической части камеры коэффициента теплоотдачи, показано на рис. 7. 


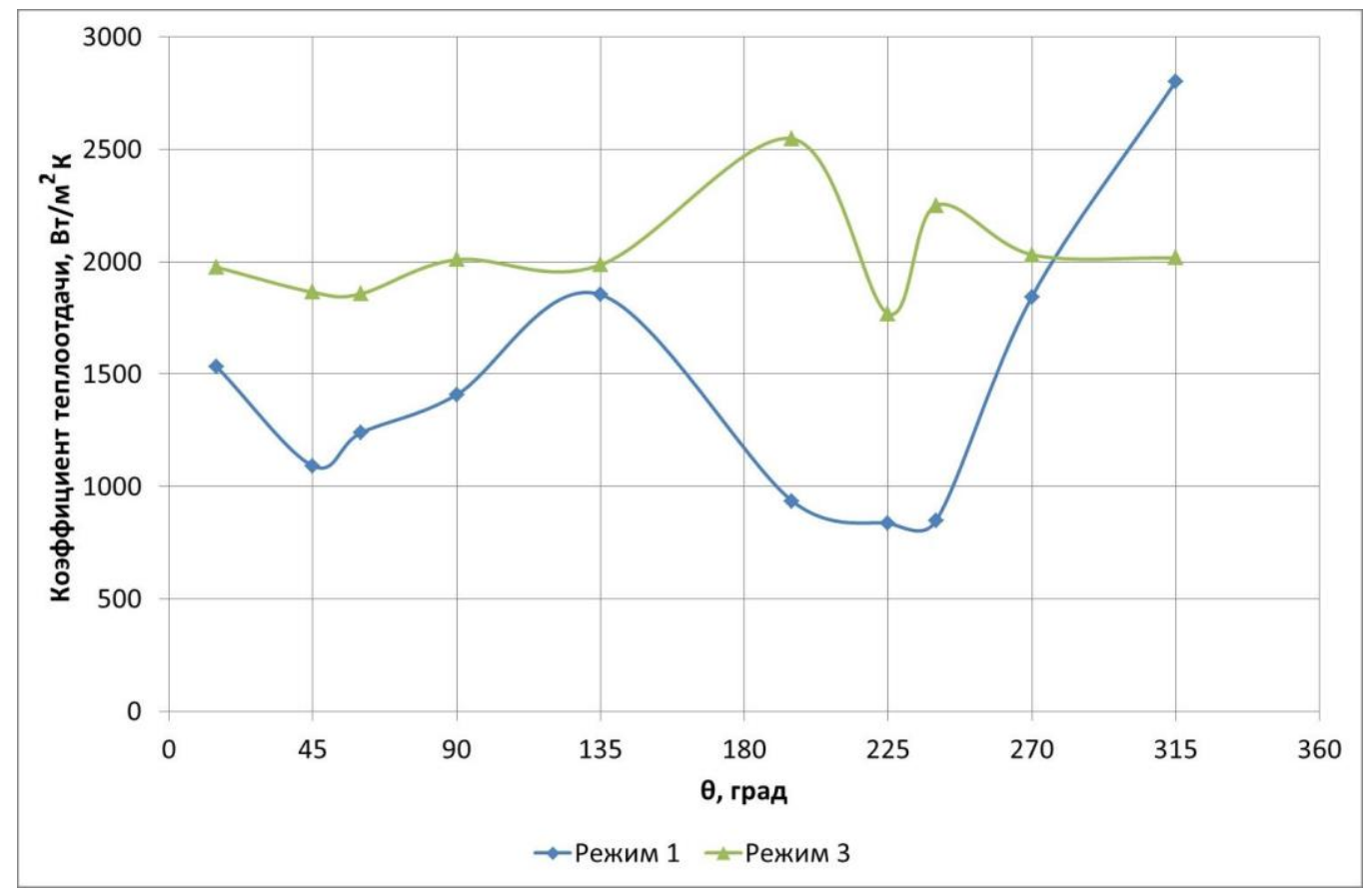

Рис. 7. Распределение среднего коэффициента теплоотдачи по сечениям камеры (режимы 1 и 3)

Из рис. 7 видно, что при увеличении частоты вращения вала с 9000 до 16000 об/мин наблюдается рост коэффрициента теплоотдачи и существенно меняется характер его распределения по окружности камеры, он имеет более равномерное распределение при высоких оборотах ротора. Это связано с тем, что увеличение частоты вращения ротора приводит к увеличению окружной скорости капель масла, движущихся в воздушном потоке, что приводит к более интенсивному их взаимодействию с поверхностью стенок камеры и пленки масла. Кроме этого, за счет увеличения силы сдвига (касательного напряжения) на межфазной поверхности пленка / воздух+капли, образующаяся пленка масла имеет меньшую толщину и более равномерное распределение по окружности камеры. Однако наблюдается, что коэффициент теплоотдачи при частоте вращения 16000 об/мин имеет максимальное значение в сечении $195^{\circ}$, а минимальное - в $225^{\circ}$, что обусловлено интенсивным взаимодействием потока капель с поверхностью пленки и значительным влиянием силы сдвига (касательного напряжения) на течение пленки масла в левой части камеры подшипника. Под действием этой силы пленка как бы «сдувается» с поверхности камеры, в результате чего ее толщина в сечении $225^{\circ}$ принимает максимальное значение, а в сечении $195^{\circ}$ наблюдается интенсивное течение пленки, что существенно влияет на величину термического сопротивления пристеночного слоя и, как следствие, на коэффициент теплоотдачи.

\section{4. Влияние расходов масла и воздуха на коэффициент теплоотдачи при ма- лых частотах вращения ротора}

Расход масла для смазки и охлаждения элементов опоры зависит от производительности нагнетающих насосов маслосистемы ГТД и характеристик форсунок. В свою очередь, расход воздуха для наддува уплотнений определяется разницей давления между компрессором в месте отбора воздуха и камерой подшипника, а также характеристиками уплотнений. Так как производительность нагне- 
тающих насосов и давление в месте отбора воздуха для наддува уплотнений напрямую связаны с оборотами двигателя, то представляет интерес исследование влияния расходов масла и воздуха на коэффициент теплоотдачи при малых частотах вращения ротора ГТД. Ниже представлено исследование теплоотдачи в камере подшипника для четырех режимов:

- $\quad$ Режим 1a: частота вращения 4000 об/мин; расход масла от подшипника 50 л/ч; расход воздуха 15 г/с.

- $\quad$ Режим 2a: частота вращения 4000 об/мин; расход масла от подшипника 24,4 л/ч; расход воздуха 15 г/с.

- $\quad$ Режим За: частота вращения 4000 об/мин; расход масла от подшипника 50 л/ч; расход воздуха 5,3 г/с.

- $\quad$ Режим 3а: частота вращения 4000 об/мин; расход масла от подшипника 24,4 л/ч; расход воздуха 5,3 г/с.

На рис.8 показано изменение осредненного вдоль цилиндрической части камеры коэффициента теплоотдачи в характерных сечениях (рис. 3).

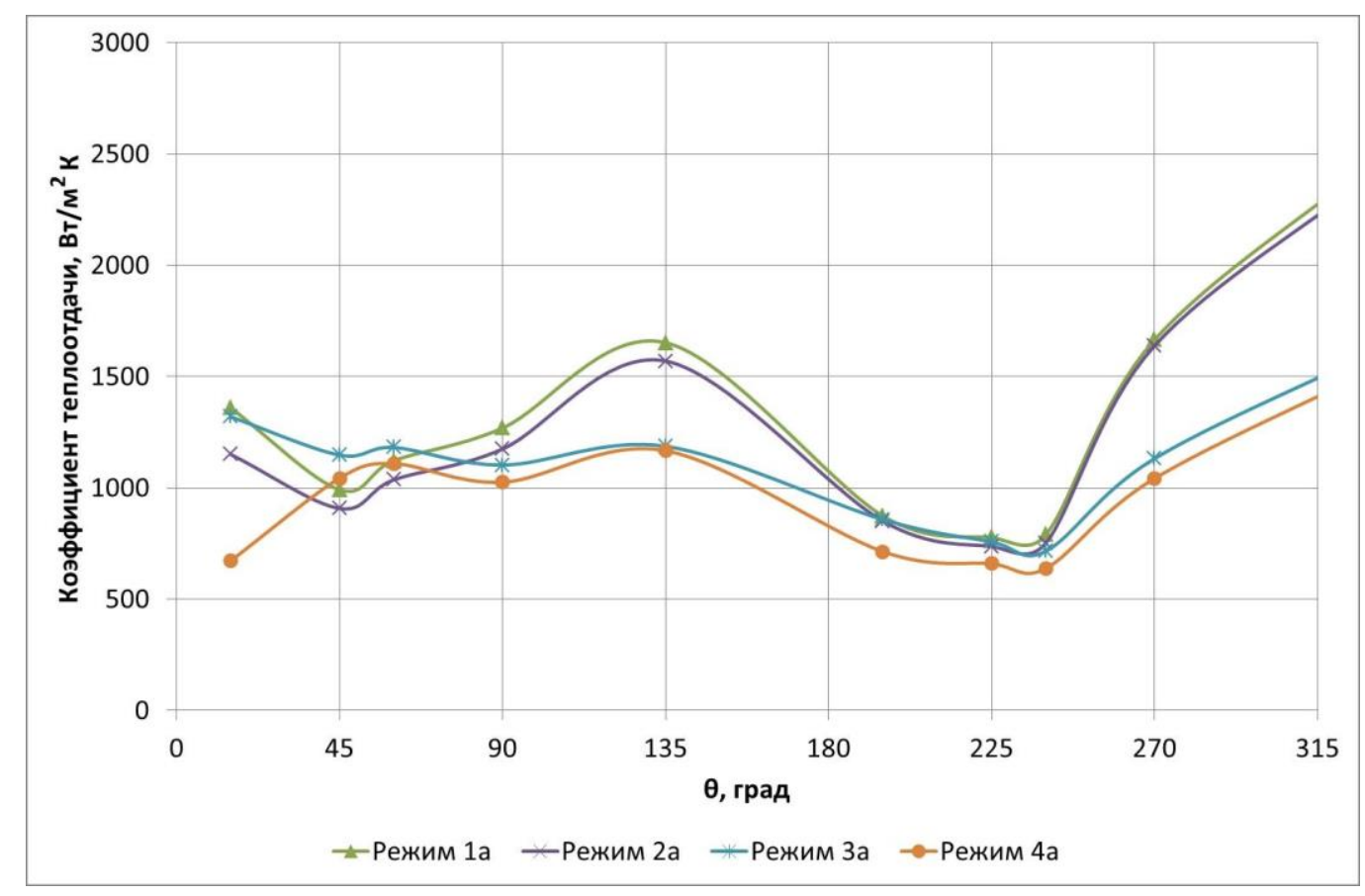

Рис. 8. Распределение среднего коэффициента теплоотдачи по сечениям камеры (режимы 1a-4a)

Как видно из рис. 8, при частоте вращения ротора 4000 об/мин уменьшение расхода масла от 50 до 24,4 л/мин приводит к снижению среднего по окружности коэффрициента теплоотдачи на 5\%, при этом сохраняется характер его распределения по окружности камеры. Уменьшение расхода воздуха от 15 до 5,3 г/с существенно меняет картину распределения коэффиццента теплоотдачи по окружности камеры и приводит к снижению его среднего значения на $25 \%$, что для режима 1а и За показано на рис. 9. 


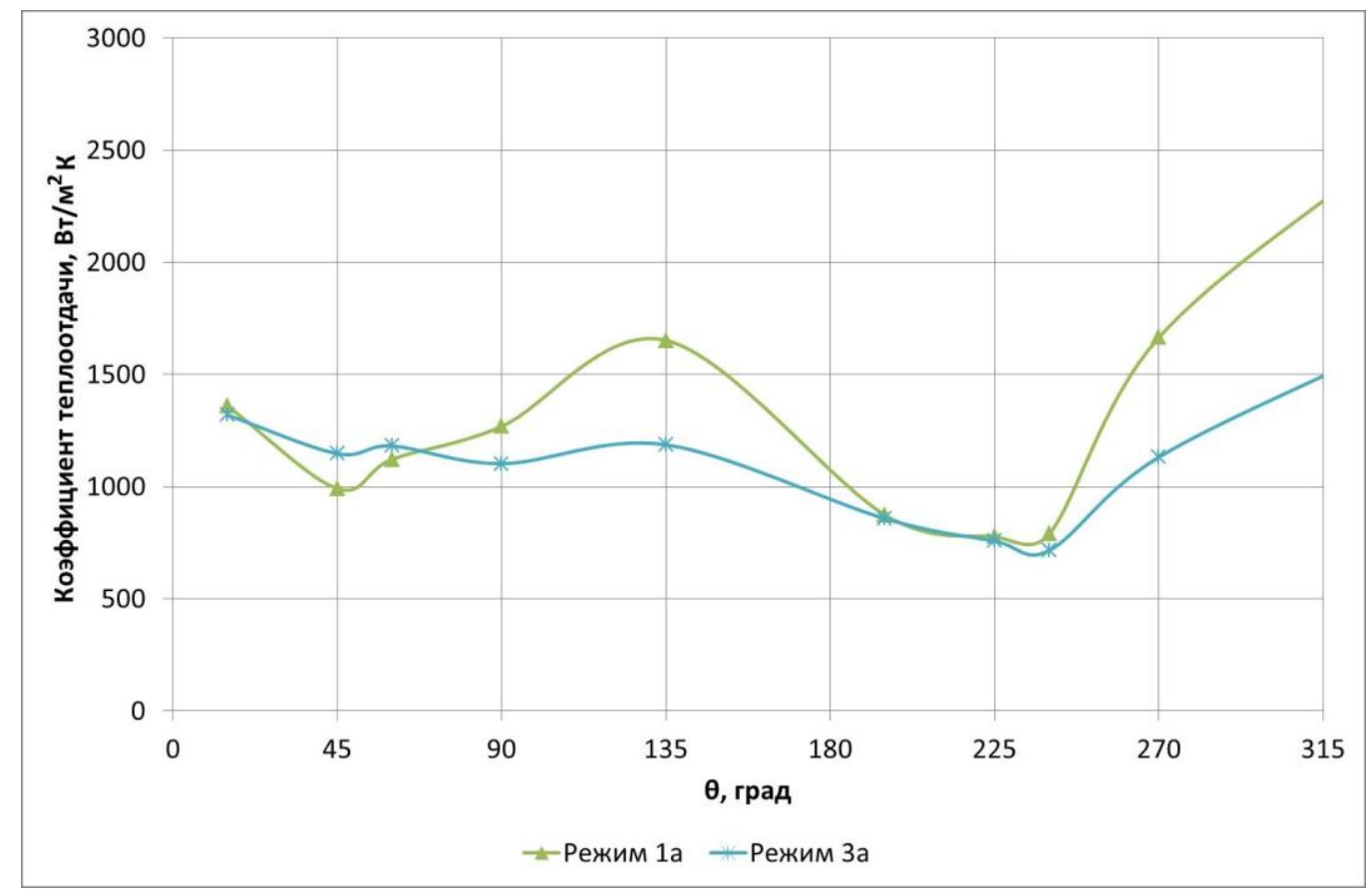

Рис. 9. Распределение среднего коэффициента теплоотдачи по сечениям камеры (режимы 1a, 3a)

Из рис. 8 и 9 видно, что минимальные значения коэффицциента теплоотдачи, как и для режимов 1 и 2 (табл. 1), наблюдаются в нижней части камеры, что соответствует угловым координатам $195 \ldots 240^{\circ}$, где происходит обильное формирование масляной пленки на стенках камеры. В верхней части камеры, особенно в области $270 \ldots 315^{\circ}$, где не происходит формирование слоя пленки на стенках камеры или формируется тонкий ее слой, поток капель уменьшает термическое сопротивление пограничного слоя, что приводит к росту коэффициента теплоотдачи.

\section{4. Проверка применимости корреляционной зависимости [3] для расчета среднего коэффициента теплоотдачи в камере подшипника}

В работе [3] Бусам и др. на основе данных экспериментальных исследований теплообмена в камере подшипника предложили безразмерное уравнение для расчета коэффициента теплоотдачи вдоль внутренней цилиндрической стенки камеры подшипника. Число Нуссельта было выражено как функция групп безразмерных параметров, количественно определяющих влияние геометрии камеры, скоростей потоков масла и воздуха, а также частоты вращения вала. Результатом этого исследования явилась обобщенная корреляция вида

$$
\mathrm{Nu}_{D_{h}}=0.35 \cdot \mathrm{D}_{h}{ }^{1.46} \operatorname{Re}_{L}{ }^{0.48} \operatorname{Re}_{F}{ }^{0.32} \operatorname{Re}_{U}{ }^{0.35},
$$

где $\mathrm{Nu}_{D_{h}}$ - число Нуссельта;

$\mathrm{D}_{h}$ - гидравлический диаметр;

$\operatorname{Re}_{L}, \operatorname{Re}_{F}, \operatorname{Re}_{U}$ - числа Рейнольдса потока масла, воздуха и ротационное, соответственно.

Область применимости этого соотношения, по словам авторов [3], ограничивается расходом масла 24,4...175,8 л/ч; расходом уплотняющего воздуха 
$5,3 \ldots 20,5$ г/с; частотой вращения вала 4000...16000 об/мин; гидравлическим диаметром 0,012...0,034 м.

Результаты расчета среднего коэфффициента теплоотдачи с использованием разработанной методологии [5] сравнивались с результатами расчета по соотношению (1). Сравнение результатов расчета представлено в табл 2.

Таблица 2

Сравнение результатов расчета коэффициента теплоотдачи

\begin{tabular}{|c|c|c|c|c|c|}
\hline \multirow[b]{2}{*}{ Режим } & \multirow{2}{*}{$\begin{array}{c}\text { Частота } \\
\text { вращения } \\
\text { вала, } \\
\text { об/мин }\end{array}$} & \multirow{2}{*}{$\begin{array}{c}\text { Расход } \\
\text { масла от } \\
\text { подшипника, } \\
\text { л/ч }\end{array}$} & \multirow{2}{*}{$\begin{array}{c}\text { Расход воз- } \\
\text { духа через } \\
\text { уплотнение, } \\
\text { г/с }\end{array}$} & \multicolumn{2}{|c|}{ Коэфрфициент теплоотдачи } \\
\hline & & & & $\begin{array}{c}\text { Методология } \\
\text { [5] }\end{array}$ & $\begin{array}{c}\text { Корреляция } \\
\text { (1) }\end{array}$ \\
\hline 1 & 9000 & 50 & 15 & 2042 & 1903 \\
\hline 2 & 9000 & 100 & 15 & 3023 & 2375 \\
\hline 3 & 16000 & 50 & 15 & 2704 & 2327 \\
\hline $1 a$ & 4000 & 50 & 15 & 1843 & 1433 \\
\hline $2 a$ & 4000 & 24,4 & 15 & 1798 & 1139 \\
\hline $3 a$ & 4000 & 50 & 5,3 & 1461 & 870 \\
\hline $4 a$ & 4000 & 24,4 & 5,3 & 1323 & 691 \\
\hline
\end{tabular}

Как видно из табл. 1, наблюдается хорошее совпадение результатов расчета коэфффициента теплоотдачи с использованием методологии [5] и корреляции (1), однако в области малых оборотов и расходов воздуха (режимы За и 4а) видно сильное расхождение между результатами расчета с использованием методологии [5] и корреляции (1), что может быть связано с достижением нижнего предела применимости корреляции (1).

\section{Заключение}

Разработанная методология позволяет численно исследовать протекание теплогидравлических процессов в камерах подшипников газотурбинных двигателей на этапе проектирования.

Количество подаваемого масла и воздуха, а также частота вращения ротора оказывают существенное влияние на картину течения в камере подшипника. Неравномерность потокораспределения приводит к переменному значению термического сопротивления пограничного слоя и, следовательно, коэфффициента теплоотдачи, что оказывает значительное влияние на тепловой поток в масляную полость опоры ротора, тепловое состояние масла и элементов опоры.

Минимальные значения коэфффициента теплоотдачи наблюдаются в нижней части камеры, что соответствует угловым координатам $195 \ldots 240^{\circ}$. В верхней части камеры, особенно в области $270 \ldots 315^{\circ}$, где не происходит формирование слоя пленки на стенках камеры или формируется тонкий ее слой, наблюдается рост коэффрициента теплоотдачи.

Увеличение расходов масла и воздуха, а также частоты вращения ротора приводит к росту коэффицциента теплоотдачи. Изменение расхода масла от 50 до 24,4 л/мин при частоте вращения ротора 4000 об/мин приводит к несущественному изменению коэффрициента теплоотдачи. 


\section{Список литературы}

1. Иноземцев, А.А. Автоматика и регулирование авиационных двигателей и энергетических установок. Системы [Текст]: Т. 5, сер. Газотурбинные двигатели / А.А. Иноземцев, М.А. Нихамкин, В.Л. Сандрацкий. - М.: Машиностроение, 2008. 200c.

2. Подходы к моделированию теплогидравлических процессов в элементах маслосистемы ГТД / Т. П. Михайленко, Д. А. Немченко, Дуаиссиа Омар Хадж Аисса, И. И. Петухов // Вісник НТУ «ХПІ». Сер.: Енергетичні та теплотехнічні процеси й устаткування. - Харків : НТУ «ХПІ», 2017. - № 10 (1232). - С.79-84.

3. Busam, S., Glahn, A., Wittig, S., 2000, Internal Bearing Chamber Wall Heat Transfer as a Function of Operating Conditions and Chamber Geometry, J. Eng. Gas Turbines Power 122(2). - P. 314-320.

4. Glahn, A., Busam, S. \& Wittig, S., 1997, Local and Mean Heat Transfer Coefficients Along the Internal Housing Walls of Aero-Engines Bearing Chambers, International Gas Turbine and Aero-Engine Congress \& Exposition, June, Colorado, Florida.

5. Численное исследование теплогидравлических процессов в камере подшипника ГТД [Текст] / Дуаиссиа Омар Хадж Аисса, Т. П. Михайленко, А. Ю. Лисица И. И. Петухов // Вестник двигателестроения. - 2018, №2. - С.70-76.

6. Wang, C, Morvan, H. P., Hibberd, S. and Cliffe, K. A. (2011), "Thin Film Modelling For Aero-Engine Bearing Chambers", Vancouver, British Columbia, Canada, ASME 2011 Turbo Expo: Turbine Technical Conference and Exposition, Vol. 1, pp. 1-10, ISBN 978-0-7918-5461-7.

7. Wolfram Kurz, Klaus Dullenkopf and Hans-Jörg Bauer. Influences on the Oil Split Between the Offtakes of an Aero-Engine Bearing Chamber. ASME Turbo Expo 2012: Turbine Technical Conference and Exposition Volume 4: Heat Transfer, Parts A and B Copenhagen, Denmark, June 11-15, 2012

\section{References}

1. Inozemtsev, A.A. Avtomatika i regulirova-nie aviatsionnykh dvigatelei i energeticheskikh us-tanovok. Sistemy: T. 5, ser. Gazoturbin-nye dvigateli / A.A. Inozemtsev, M.A. Nikhamkin, V.L. Sandratskii. - M.: Mashinostroenie, 2008. - 200s.

2. Mykhailenko, T. P. Podkhody k modelirova-niyu teplogidravlicheskikh protsessov v elementakh maslosistemy GTD / T. P. Mykhailenko, D. A. Nem-chenko, Douaissia Omar Hadj Aissa, I. I. Petukhov // Visnik NTU «KhPI». Seriya: Energetichni ta teplotekhnichni protsesi i ustatkuvannya. - Kharkiv : NTU «KhPI», 2017. - № 10 (1232). — S.79-84.

3. Busam, S., Glahn, A., Wittig, S., 2000, Internal Bearing Chamber Wall Heat Transfer as a Function of Operating Conditions and Chamber Geometry, J. Eng. Gas Turbines Power 122(2), 314-320.

4. Glahn, A., Busam, S. \& Wittig, S., 1997, Local and Mean Heat Transfer Coefficients Along the Internal Housing Walls of Aero-Engines Bearing Chambers, International Gas Turbine and Aero-Engine Congress \& Exposition, June, Colorado, Florida.

5. Duaissia Omar Hadzh Aisca. Chislennoe issledovanie teplogidravliche-skih processov v kamere podshipnika GTD / Duaissia Omar Hadzh Aisca, T. P. Mihajlenko, A. Ju. Lisica I. I. Petuhov // Vestnik dvigatelestroenija. - 2018, №2. - S.70-76.

6. Wang, C, Morvan, H. P., Hibberd, S. and Cliffe, K. A. (2011), "Thin Film Modelling For Aero-Engine Bearing Chambers", Vancouver, British Columbia, Canada, ASME 
2011 Turbo Expo: Turbine Technical Conference and Exposition, Vol. 1, pp. 1-10, ISBN 978-0-7918-5461-7.

7. Wolfram Kurz, Klaus Dullenkopf and Hans-Jörg Bauer. Influences on the Oil Split Between the Offtakes of an Aero-Engine Bearing Chamber. ASME Turbo Expo 2012: Turbine Technical Conference and Exposition Volume 4: Heat Transfer, Parts A and B Copenhagen, Denmark, June 11-15, 2012.

Поступила в редакцию 27.09.2018

\section{Числове дослідження тепловіддачі в камері підшипника ГТД}

Для визначення потрібної прокачки масла через опору ротора ГТД потрібним $€$ точний розрахунок теплового потоку від двигуна в камеру підшипника ГТД. Складність математичного опису теплогідравлічних процесів пов'язана з наявністю багатофазної суміші в камері підшипника, що складається з масла, що йде на мащення та охолодження елементів опори, та повітря, що використовується для наддування ущільнень. Робота присвячена питанням числового дослідження впливу режимних параметрів на коефіцієнт тепловіддачі в камері підшипника ГТД. Для цього застосовано методологію, що базується на законах збереження та методах CFD моделювання. Розглянуто зміну коефіцієнта тепловіддачі в характерних перерізах камери. Показано вплив розподілу масляної плівки по колу камери на коефіцієнт тепловіддачі.

Ключові слова: газотурбінний двигун, режимні параметри, коефіцієнт тепловіддачі, опора ротора, камера підшипника, CFD-моделювання.

\section{Numerical Investigation of Heat Transfer in the GTE bearing chamber}

To determine the required oil pumping through the GTE rotor support, an accurate calculation of the heat flow from the engine to the GTE bearing chamber is necessary. The complexity of the mathematical description of thermo-hydraulic processes is associated with the presence of a multiphase mixture in the bearing chamber, consisting of oil, going for lubrication and cooling of the support elements, and air, used for seals pressurization. The work is devoted to the issues of numerical study of the effect of regime parameters on the heat transfer coefficient in the bearing chamber of the GTE. For these purposes, the methodology based on conservation laws and CFD modeling methods is applied. The change in the heat transfer coefficient in the characteristic sections of the chamber is considered. The influence of the oil film distribution around the circumference of the chamber is shown.

Key words: gas turbine engine, regime parameters, heat transfer coefficient, heat flux, rotor support, bearing chamber, CFD-simulation.

Дуаиссиа Омар Хадж Аисса - аспирант каф. аэрокосмической теплотехники, Национальный аэрокосмический университет им. Н. Е. Жуковского «ХАИ», Харьков, Украина, e-mail: douaissia.omar@hotmail.fr. 